\title{
IMPROVEMENT OF METHODS OF ESTIMATING THE CHANGE IN THE ECOLOGICAL STATE OF SOILS UNDER THE INFLUENCE OF EXTERNAL LOADS
}

\author{
A. S. Kholodna, K. O. Desiatnyk \\ National Scientific Center "Institute for Soil Science and Agrochemistry \\ named after O.N. Sokolovsky" NAAS of Ukraine \\ 4, Chaikovsky Str., Kharkiv, Ukraine 61024 \\ e-mail: lonakalt@gmail.com
}

Received on February 28, 2018

\begin{abstract}
Aim. The aim of this work is to optimize and facilitate current methods of ecological diagnostics of soils of different genesis under the influence of various external loads. Methods. Laboratory-modelling (physicalchemical, biological): determination of acid-base buffer ability of soil (DSTU 4456:2005); determination of the activity of calcium ions (DSTU 4725:2008); determination of the activity of protease was performed by modified Mishustin's method. Results. The methods, proposed by us, speed up the ecological diagnostics of soils considerably regardless of their origin and external factors. This facilitates monitoring of soil resources and reveals the factors that influence the course of soil processes negatively or positively. These methods have already become the basis of "Methodology of operational diagnostics of the influence of natural and anthropogenic loads on the functional stability of acid soils". The proposed methods can be used not only by the scientists of specialized scientific institutions, but also by farmers (in case of available minimal instrumental equipment). Conclusions. A modified photoautography method has been developed on the basis of the laboratory of hydromorphic and acid soils fertility of the NSC ISSAR named after O.N. Sokolovsky, NAAS of Ukraine, for the determination of enzymatic activity by the parameters of the protease enzyme. The abovementioned technology is based on Mishustin's method of determining protease activity. In addition, this method may be used to determine the rate of protease action in different soils under various tillage conditions and under different loads. The diagnostics of acid-base state of soils by ion-selective methods with the determination of the levels of activity of calcium ion and soil $\mathrm{pH}$, modeling of the loads on soils (natural and anthropogenic), determination of acid-base buffer capacity change of soil under the influence of loads and determination of biological activity due to the activity of protease allow to determine the functional stability of each soil in rather a short period of time in order to further increase/maintain it. As the final stage of the diagnostics, we proposed a formula of calculating the coefficient of functional stability of soils ( $\mathrm{K}$ f.st.), based on their genetic features. It is also very important that this scientific development does not require high financial costs, and gives the fullest possible picture of the soil state in the current period.
\end{abstract}

Keywords: functional stability, buffer ability, activity of protease, coefficient of functional stability.

DOI: 10.15407 /agrisp5.01.059

\section{INTRODUCTION}

Due to the desire to obtain maximal yields, there has been an increase in anthropogenic load on soils, related to the use of physiologically acid fertilizers, pesticides, herbicides, chemical meliorants of different quality degree as well as the use of green manure crops as "substitutes" of manure, which lead to the acidity of soils as

(C) A. S. KHOLODNA, K. O. DESIATNYK, 2018 a result of fast mineralization of their fresh and highly labile organic matter. At the same time, the soils are prone to stress due to global climate changes, as the expected increase in the soil temperature enhances the dissociation of organic acids in soil, the intensity of the impact of soil biota on the mineralization of organic matter and additional formation of acid-forming oxides of nitrogen, sulphate and carbon. Therefore, at present some of the main diagnostics criteria of the functional 


\section{KHOLODNA et al.}

stability of soils should be its operational efficiency and ability to reflect the "health" of soil [1].

The traditional system of the agrochemical and agroecological diagnostics of the state of soils is mostly based on the complex of such agrotechnical and physical-chemical indices as $\mathrm{pH}$ level, hydrolytic acidity, the sum of absorbed bases, the degree of saturation with bases, the content of mobile aluminum, the content of heavy metals, biological indices and, less frequently, physical indices. The determination of the content of any substances in soil using traditional analytical methods is a labor- and time-consuming process as it involves selecting and transporting samples and their laboratory and chemical analyses.

We proposed a convenient resource-saving and, more relevantly, rather cheap development - the operational diagnostics of the functional stability of soils under the impact of natural and anthropogenic loads. The diagnostics is made in several stages: potentiometric studies in-situ, simulating the loads (natural and anthropogenic), diagnostics of changes in soil via bioindication using the organisms, sensitive to the environmental changes, and determination of acid-base buffer ability of soils. This method ensures complex estimation of the efficiency of soil functioning [1].

It should be noted that the coefficient of functional stability of soil ( $\mathrm{K} \mathrm{f.st}$.) as an integral index of physical-chemical (buffer ability and activity of calcium) and biological (activity of protease enzyme) properties of soil was proposed for the first time. This is a substantial factor, taking into consideration the soil as a living biological body which can be presented not via separate components but only via their specific combination [1].

As buffer properties of soils play a relevant role in the stabilization of soil fertility and in the estimation of evolutionary direction of the fertility potential of soils, this property was selected by us as one of the components with the greatest impact on the soil stability. The buffer capacity regarding a specific element of fertility is a reliable criterion of its stability and an actual cumulative index for the estimation of the functioning of the nutrition regime by a specific element of fertility.

The acid-base state of soil is one of key indices of its fertility. The acid-base balance of soils is directly connected to the content of alkaline and alkaline-earth cations as the main antagonists of hydrogen and other elements, which have their impact on the formation of $\mathrm{pH}$ level. It is the balance of these elements in soil that defines the vector of direction of soil processes towards acidification or, vice versa, alkalization of the soil medium.

The value of active or potential acidity or alkalinity is often not an objective characteristic of the acid-base function of soils. It is more important in the theoretical and practical sense to have clear determination of the level of susceptibility of soils to the acidification or, vice versa, alkalization. The application of the recent achievements of soil studies towards the use of theoretical and practical provisions of the buffer ability of soils allows eliminating these drawbacks [2].

The example of diagnostics and optimization of the acid-base status of a specific type of soils is presented in the works [3-7].

Talking about the soil stability, it is impossible to omit calcium which is a relevant component of soil stability as a natural body. It is also one of relevant macroelements of the nutrition of plants, a factor of soil structuring and humus stabilization, and also a regulator of soil acidity. Therefore, the stability of reserves of soil calcium and the optimization of processes of its accumulation-dissipation in soil is an urgent issue. The latter is especially urgent in modern conditions of climatic instability due to the accumulation of carbon dioxide in the atmosphere, and thus - to the hazard of shifts in the carbonate equilibrium.

Soil processes involving calcium are characterized via a group of potentials, among which a prominent place is given to the lime potential $\mathrm{pH}-0.5 \mathrm{pCa}$ or the potential of hydrogen-calcium exchange.

The methods, based on determining the hydrolytic acidity, saline and water $\mathrm{pH}$ in soils, prevail among many current methods of diagnostics and optimization of the acid-base balance in soils.

Soil microorganisms are the pioneers of the soilforming process. They determine the biological activity of soils, their fertility and ecological status to a large degree. However, at present their ability of serving as indicators of "soil health" is becoming more urgent. It is microorganisms that are some of the first to react to the slightest environmental changes, therefore, their reactions to different pollutants, more often - heavy metals $[8,9]$, or fluctuations in the existence conditions are very valuable for ecological monitoring, including soil monitoring.

As for microbiota, a considerable role is played by enzymes - organic catalysts of protein nature, accumu- 


\section{IMPROVEMENT OF METHODS OF ESTIMATING THE CHANGE IN THE ECOLOGICAL STATE OF SOILS}

lated in soil in the process of activity of living organisms. Due to enzymes, there are processes of humus accumulation and restoration in soils, the trophic and sanitary functions are activated, etc. However, natural catalysts are often inhibited due to the following factors: the application of intensified soil tillage $[10,11]$; the pollution of soil with pesticides [12]; the formation of specific natural compounds such as tannins [13] and terpenes [14] in soils under forest plants and microcystins in the soils of lacustrine deposits [15]; the pollution of environment [16], etc.

The enzymes take a considerable share of soil fauna, therefore, the improvement of their living conditions is one of the most important tasks of ecological soil studies in current conditions of intensifying agriculture. In particular, the use of the scientifically grounded system of tillage and fertilization of soil $[10,17]$ promotes the increase in populations of different microorganisms. However, due to popularization of resourcesaving methods, there are new ways of optimizing the microbial regime of soils in the world. One of these methods is covering oak (and other kinds) of biochar with the arable layer of soil $[18,19]$. It was proven that this leads to the increase in the amount of total organic carbon and microbiological activity, and, as a result, in soil quality.

The degradation processes are of dual nature - natural and anthropogenic. A new issue of soil studies is the recultivation and restoration of disturbed soils of urbanized areas. Recently, there has frequently been a new term in the literature - "urban soils" - anthropogenically modified [20] soils of urban territories, the artificial profile of which has a surface layer of up to $50 \mathrm{~cm}$, created by humans by molding, mixing, burying materials (substrates) of purely urbanogenic origin [21]. Therefore, the functions and properties of such soils are subject to considerable disturbance, especially in terms of functioning of their biological component.

We were interested in the studies on ecologically sensitive soils of urbanized areas (urban soils) with the purpose of activating their biological component and, as a result, partial self-restoration. The cultivation of several kinds of energy crops was suggested as they have a positive influence on the status of soil fauna and the activity of protease enzyme [22, 23] not only on urban soils but also on a number of other types of soils. It is noteworthy that such energy crops as giant miscanthus (Miscanthus Giganteus) and willow (Salix) are also decorative plants, which is especially valuable while cultivating them in urbanized zones.
Protease activity is one of integral indices of the total biological activity of soils, a potential ability of soils to decompose proteins and peptides [24]. Protease takes part in the mobilization and circulation of nitrogen. The higher the content of mobile nitrogen and other elements of nutrition in soil is, the more active the process of cellulose oxidation is. The cellulose-decomposing microorganisms ferment the fiber, synthesize and partially release aminoacids into the medium.

Protease is considered to be one of the most important enzymes in the soils of chernozem type, but one should not underestimate its positive action in other soil types as well. The determination of protease activity in acid and forest soils, the soils which suffered from degradation processes is an efficient method of soil-ecological monitoring. The degraded soils present a wide field for studies in the sphere of ecological soil studies, as they are the first to be subject to recultivation, which are ecologically safe due to their susceptibility [25].

The biological restoration and maintaining the fertility of soils, both degraded ones and those with undisturbed structure, is impossible without the consideration of microbiological, and thus enzymatic component. The special place in our work is given to protease as an enzyme, taking part in the transformation of nitrogenous compounds. The determination of protease activity was paid much attention in the previous century, but even after many years of studies there are many gaps in the literature regarding the response of protease to foreign factors [26]. Current methods of estimating the activity of this enzyme are characterized by much labor and the application of rather a large amount of reagents and devices. In addition, the deviations of these analyses are rather substantial.

We have improved Mishustin's method of determining protease activity and elaborated an accurate express-mechanism of determining a quantitative index of protease activity of soil, which ensures considerable facilitation and acceleration of current methods and obtaining objective data about the soil quality. It is also important that this method is easily applied in practice with just a required minimum of materials. Therefore, the suggested method has considerable advantages compared to current ones.

It would be reasonable to determine the advantages of the methods, suggested by us, with current ways of determining the abovementioned indices.

First of all, the determination of any soil indices directly in the field is surely a faster and less expensive 


\section{KHOLODNA et al.}

method, because it does not require time and material resources for the preparation and transportation of samples, the acquisition of reagents, etc. Therefore, the advantage of the potentiometric method of studying the acid-base status of soils is obvious.

Up till now there have been several methods of determining the biological activity of soils, but all of them are rather complicated in terms of implementing, and the process of obtaining results is very time-consuming. The following methods have proven to be most commonly used: the method, based on the application of cellulose standards [27]; the method using the intensity of flax linen decomposition [28]; the method of determining the proteolytic activity of soils using photopaper or photofilm [29].

Taking into consideration the fact that in modern world the preference is given not only to quality but also to the rate of obtaining the results, the following method of estimating changes in the ecological status of soils will ensure considerable acceleration of the ecological monitoring of soils of different genesis and, as a result, the restoration of their physical and biological properties.

\section{MATERIALS AND METHODS}

Potentiometric, biological methods and the methods of determining acid-base buffer capacity were used during the studies.

The estimation of acid-base status of soils is done efficiently via direct potentiometric determination using ion-selective electrodes, as it allows estimating directly in soil without taking a sample, and it does not require any processing of soil material in the laboratory conditions except for diluting with water.

The activity of a substance in soil, determined potentiometrically, is active content of this substance in the aqueous phase in the field soil, or in conditions, maximally close to the field soil.

The activity is usually measured in milligram-equivalents per one liter of soil solution: $a$, [mg-eq/1], or presented in the form of a logarithmic index, similar to $\mathrm{pH}: \mathrm{p} a=-\lg a$. To transfer to milligrams per liter, one should multiply the value of $\boldsymbol{a}$ by atomic or molecular mass of the investigated element, referred to the unit of its valency (equivalent mass). To transfer to the content in soil, one should consider the content of aqueous phase in it (humidity) [2].

As for exchange cations of calcium $\left(\mathrm{Ca}^{++}\right)$, the activity should be interpreted as active content of mobile water-soluble form.
Any potentiometric estimation is efficient for direct study of the dynamics in the mobile substance in soil as well as for the determination of the spatial variability (diversity) of this content - for instance, to find "spots" in order to correct the norms of fertilizers in the fields which is especially relevant in the practice of directed agriculture [2].

At present, there is a common method of potentiometric determination of $\mathrm{pH}$. Calcium may be determined according to DSTU 4725:2008.

The method of determining the acid-base buffer of soil is based on estimating the change in $\mathrm{pH}$ of the soil suspension due to the addition of increasing doses of acid and alkali. It is determined according to DSTU 4456:2005. The results are presented in a graphic form as a dependence of $\mathrm{pH}$ the dose of additive (ad). The obtained curve of pH-buffer capacity is the basis for normative forecast of the needs of chemical melioration of some soils.

The acid part of the buffer capacity for acid soils was taken by us as negative part of $\mathrm{pH}$-buffer capacity and the alkali part - as a positive part. The main indices of $\mathrm{pH}$-buffer capacity of soils are as follows:

- buffer capacity of soils in the alkali part (interval) of loads $\left(\mathrm{BC}_{\mathrm{Al}}\right)$;

- buffer capacity of soils in the acid part (interval) of loads $\left(\mathrm{BC}_{\mathrm{Ac}}\right)$;

- the coefficient of buffer asymmetry (CBA) - the ratio of the difference and sum of the abovemen tioned capacities

$$
\begin{aligned}
& \mathrm{BC}_{\mathrm{Al}}-\mathrm{BC}_{\mathrm{Ac}} \\
& \mathrm{BC}_{\mathrm{Al}}-\mathrm{BC}_{\mathrm{Ac}}
\end{aligned}
$$

- the total estimation index of buffer capacity (TEIBC), which includes the sum of buffer capaci ties with the consideration of the asymmetry coef ficient, determined by the formula:

$$
\left(\mathrm{BC}_{\mathrm{Al}}+\mathrm{BC}_{\mathrm{Ac}}\right)(1-|\mathrm{CBA}|) \text {. }
$$

The lower the asymmetry coefficient is, the higher is the rate of the reverse processes or the rate of selfregulation of genetically inherent acid-base balance of soils.

The diagnostics and optimization of the acid-base status of specific soil was conducted in the following way:

- determining optimal values of $\mathrm{pH}$ of the soil solution for crops; 


\section{IMPROVEMENT OF METHODS OF ESTIMATING THE CHANGE IN THE ECOLOGICAL STATE OF SOILS}

- building the chart of $\mathrm{pH}$-buffer capacity for specific soil, distinguishing the optimal $\mathrm{pH}$ zones on the chart;

- determining the optimal $\mathrm{pH}$ level of soil within a specific crop rotation, reaching which requires the estimation of the meliorant dose;

- calculating and introducing the corresponding dose of the meliorant into soil to reach the given rate.

The estimation of the enzymatic activity by the indices of protease activity was performed by the modified photoautography method on the basis of the laboratory of fertility of hydromorphic and acid soils of NSC ISSAR named after O. N. Sokolovsky. The abovementioned technology is based on Mishustin's method of determining protease activity [28].

Photofilms were used as application material. We have improved the method of estimating the protease activity using the graphic editor Adobe Photoshop.

The estimation of proteolytic activity requires the following items: soil samples (50 $\mathrm{g}$ - the mass of one sample); Petri dishes; unexposed film; distilled water.

A piece of film is placed on the bottom of a Petri dish (films of $2.5 \mathrm{~cm} \times 7.5 \mathrm{~cm}$ were used in our study) with the gelatin layer upwards. Maximally homogenized soil with the weight of $50 \mathrm{~g}$ is placed onto the film. One of our tasks was to determine the rate of complete decomposition of the gelatin layer of the film, therefore, we moistened soil samples with distilled water up to $80 \%$ from the complete water capacity of soil.

The films were extracted 3-5 days later, depending on the type of soil. For further estimation of the quantitative value of protease activity, the films are carefully washed with distilled water, dried and fixed to carton, preferably of black or yellow color (the most convenient colors for further work in the graphic editor). The obtained films are scanned. The film with non-decomposed gelatin is taken as the control.

The scanned image is opened using the graphic editor Adobe Photoshop. A graphic document is created with the sizes of $2.5 \times 7.5 \mathrm{~cm}$ with transparent background and the resolution of 78.74 pixels per one centimeter $(\mathrm{px} / \mathrm{cm})$. The area with the photofilm is outlined on the scanned image, copied and pasted into a previously created file, then scaled.

Using the instrument "Select $\rightarrow$ Color range", select the color of the background (which is the decomposed layer of gelatin) with an eyedropper, here the value of the command "the range" should be 200 for maximal accuracy. Then, the instrument "Histogram" should be opened, which indicates in pixels the areas of the whole image (in our case this is 116427 pixels), and of the decomposed gelatin layer - i.e. the immediate background of the image. Using the ratio of the areas of variants with the decomposed gelatin and the control sample, we receive the value of the total biological activity of soil in percentage.

The final stage of operational diagnostics of the functional activity of soils is the actual calculation of the coefficient of their functional stability. Due to the fact that the acid-base buffer capacity of soil is an integral index, reflecting the changes therein (fluctuations in $\mathrm{pH}$ and $\mathrm{pCa}$ ) and soil capacity to counteract the external load, this index should be one of the main ones to determine the soil stability.

However, it is impossible to have objective estimation of the soil reaction to the exogenous impact, neglecting the living component of soil. Therefore, we proposed the following variants of the formula of calculating the coefficient of functional stability of soils ( $\mathrm{K}$ f.st.), based on their genetic features:

- for turf-podzolic soils $-\mathrm{K}$ f.st. $=0.4 \times \mathrm{B}+0.6 \times \mathrm{P}$;

- for gray forest soils $-\mathrm{K}$ f.st. $=0.6 \times \mathrm{B}+0.4 \times \mathrm{P}$;

- for podzolic chernozem $-\mathrm{K}$ f.st. $=0.7 \times \mathrm{B}+0.3 \times \mathrm{P}$;

- for meadow soils $-\mathrm{K}$ f.st. $=0.5 \times \mathrm{B}++0.5 \times \mathrm{P}$;

where $\mathrm{B}$ - the ratio of the value of the total estimation index of buffer capacity (TEIBC) of the investigated soil under the impact of anthropogenic or natural loads and the value of TEIBC of the same soil without any loads; $\mathrm{P}$ - the ratio of the value of protease activity of the investigated soil under the impact of the anthropogenic or natural loads and the value of protease activity of the same soil without any loads.

Taking into consideration the fact that turf-podzolic soils have the smallest buffer capacity, its role in maintaining the functional stability of soils will be less significant compared to gray forest and chernozem soils. Meadow soils are distinguished by high buffer capacity and considerable biological diversity, i.e. these indices have equal impact on their properties. Therefore, we suggested the abovementioned ratio of the index of the buffer capacity - TEIBC and the biological index PA, the combination of which is the coefficient of the functional stability of soils. 


\section{KHOLODNA et al.}

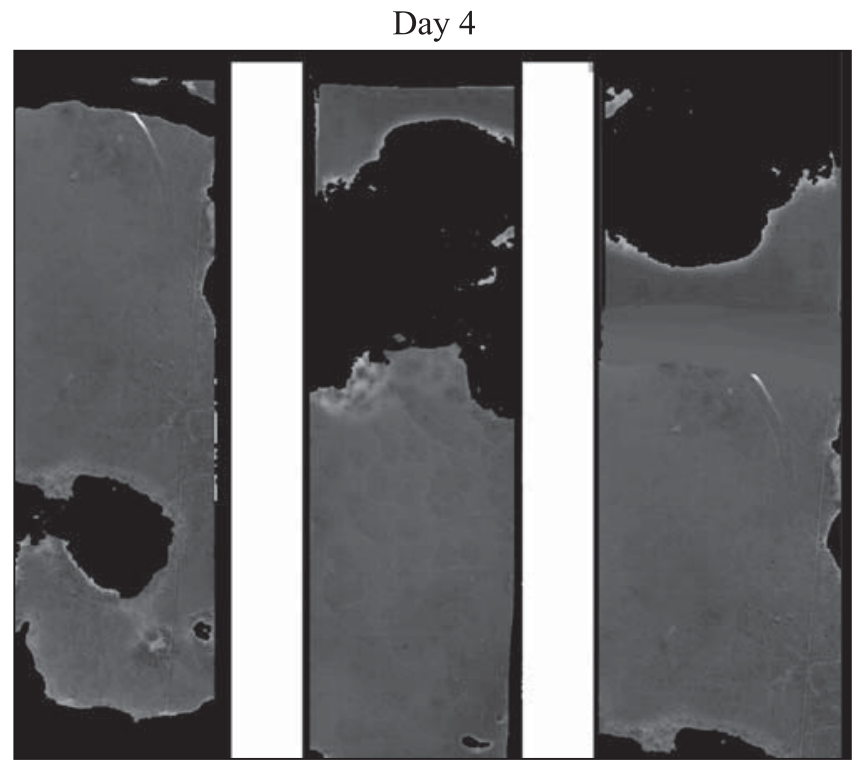

Fig. 1. The digitized image of a photofilm on the 4th day of the experiment

\section{RESULTS AND DISCUSSION}

It is noteworthy that the results of further estimations will depend on the quality of scanned image and the color of the background. Further visualization requires editing the image in the graphic editor, as shown in Figure 1.

Below is the algorithm of calculating the proteolytic activity for images with the resolution of $78.74 \mathrm{px} / \mathrm{cm}$ and the films with the size of $2.5 \times 7.5 \mathrm{~cm}$ :

the area of one square centimeter in pixels: $\mathrm{S}=$ $=78.74 \times 78.74=6200 \mathrm{px}$; the area of the film in pixels: $\mathrm{S}$ of the film $=116427 \mathrm{px}$.

Checking: a) Sfilm $=2.5 \times 7.5=18.8$ sq.cm; b) Sfilm $=116427 / 6200=18.8$ sq.cm; the area of the decomposed gelatin layer in square centimeters: $\mathrm{Sg}=\mathrm{Sg}(\mathrm{px}) / 6_{200}$;

proteolytic activity in $\%: \mathrm{PA}=\mathrm{Sg} / \mathrm{Sfilm} \times 100$.

Based on the data obtained, the analysis of different kinds of soils demonstrated that it is possible to compare the results of the control and the obtained variants of the experiment in laboratory conditions with the indicated moisture capacity as early as 3-4 days later. Table 1 presents the data of observations of the process of decomposition of the gelatin layer of the film in soils on the third day of the experiment. According to the results obtained, it is possible to check the sufficiency of the process duration of 3 days as on the $4^{\text {th }}-5^{\text {th }}$ day the gelatin layer is almost completely destroyed on all the films.

In addition, this method may be used to determine the rate of protease action in different soils under various tillage conditions and under different loads, as shown in the charts below (Fig. 2-3).

Table 2 demonstrates the change in the coefficient of functional stability of soils under the impact of anthropogenic loads on the soils of agricultural purpose, and the change in the coefficient on the soils (including degraded ones) where crops are not cultivated. In addition, we calculated the coefficient of functional stability of soils while cultivating energy crops.

Table 2 demonstrates that the highest stability is notable for chernozem. Turf-podzolic soils are more inclined to losing functional stability under the impact of external loads.

\section{CONCLUSIONS}

Current methods of estimating the protease activity of soils were optimized which allowed reproducing this

Table 1. The protease activity of soils of different genesis (in conditions of moistening the samples up to $80 \%$ from the moisture capacity)

\begin{tabular}{l|c|c|c|c|c}
\hline \multicolumn{1}{c|}{ Name of soil } & PA I, \% & PA II, \% & PA III, \% & Mean, \% & HCP $\%$ \\
\hline Typical moderately washed chernozem & 76.90 & 73.59 & 75.72 & 75.40 & 1.32 \\
Common moderately washed chernozem & 51.54 & 49.03 & 50.53 & 50.37 & 1.87 \\
Turf-podzolic & 4.85 & 5.62 & 5.15 & 5.21 & 2.02 \\
Meadow alluvial & 45.05 & 45.18 & 44.65 & 44.69 & 4.04 \\
Meadow-swamp alluvial & 34.55 & 37.12 & 34.13 & 35.27 & 5.15 \\
Chernozem urban soil & 39.30 & 39.81 & 38.18 & 39.10 & 2.11 \\
Lithozem urban soil & 38.44 & 41.91 & 40.74 & 40.36 & 2.81 \\
Chernozem-meadow urban soil & 70.67 & 72.07 & 71.36 & 71.37 & 4.58 \\
\hline
\end{tabular}




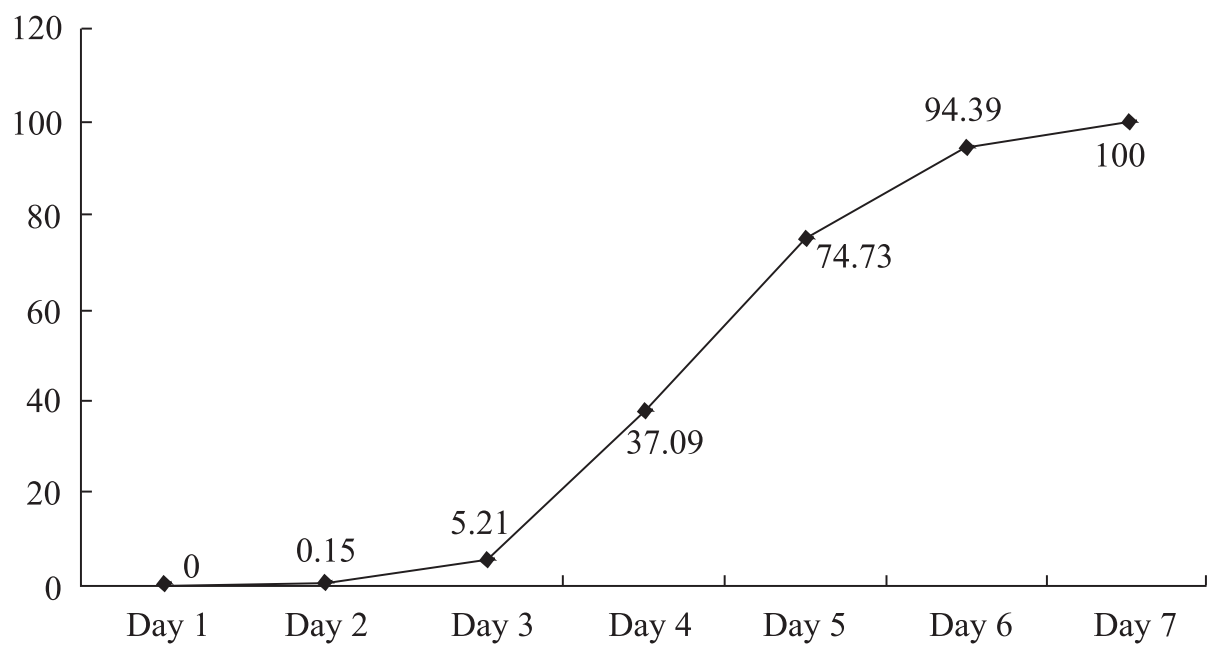

Fig. 2. The rate of gelatin decomposition on the photofilm (turf-podzolic soils)

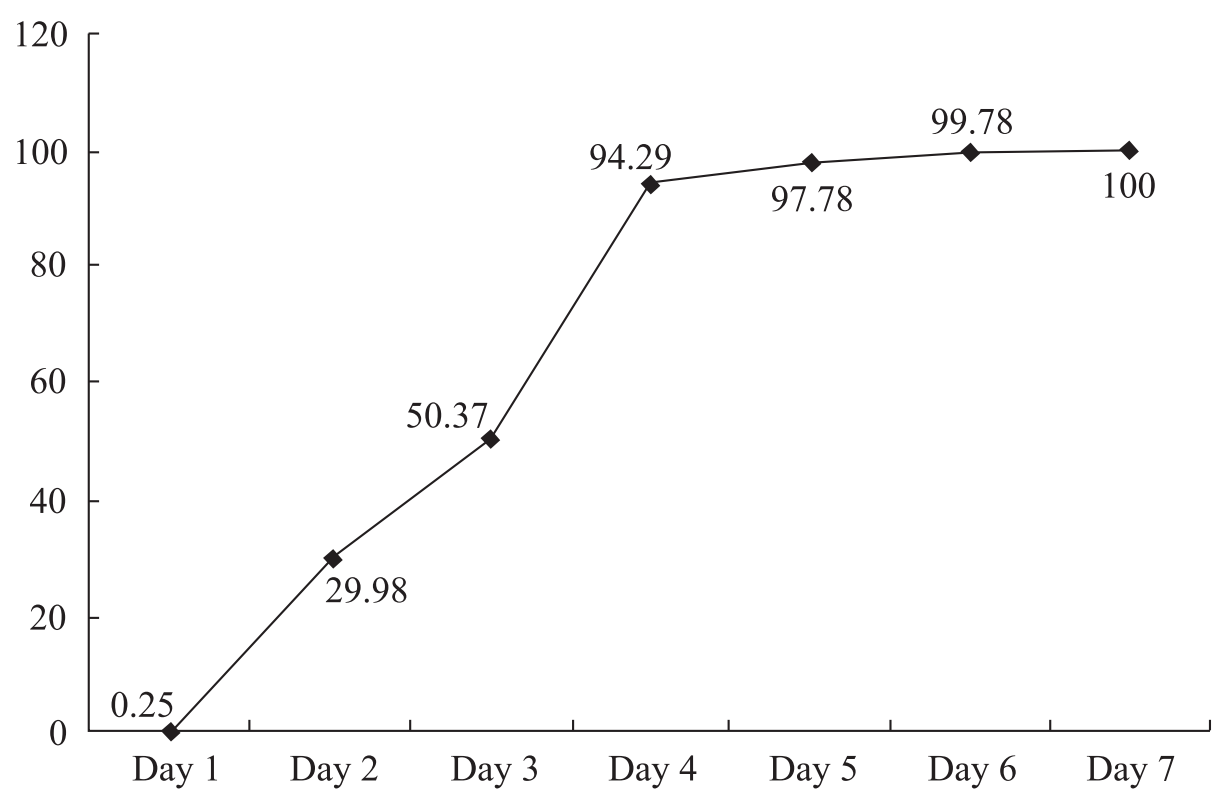

Fig. 3. The rate of gelatin decomposition on the photofilm (chernozem soils)

analysis using a personal computer and a few laboratory devices.

In modern conditions of intense increase in the anthropogenic load on environment, some of the main criteria of diagnostics of the functional stability of soils should be its operational ability, as many types of soils are susceptible to changes due to external loads, thus, there is an urgent need for timely revelation of these changes with the purpose of efficient management of their fertility.

The algorithm of estimating the functional stability of soils was suggested for the first time. It includes a number of simple stages which do not require much labor or cost and allow obtaining the data regarding spe- cific type of soil in a short period of time. The stages are as follows:

diagnostics of acid-base status of soils using ion-selective methods and determining the rates of activity of calcium ion and $\mathrm{pH}$ of soil;

simulating the loads (natural and anthropogenic ones) on soils;

diagnostics of changes in the biological activity of soils using the operational method of determining the protease activity in it;

determining the changes in the acid-base buffer capacity of soil under the impact of loads;

calculating the coefficient of functional stability of soils. 
KHOLODNA et al.

Table 2. The functional stability of soils with different acid-base balance under the impact of anthropogenic loads

\begin{tabular}{|c|c|c|c|}
\hline Variant & TEIBC, points & $\mathrm{PA}, \%$ & K f.st. \\
\hline \multicolumn{4}{|c|}{ Turf-podzolic soils } \\
\hline Control & 13.3 & 37.0 & 1.00 \\
\hline NPK & 11.4 & 25.0 & 0.74 \\
\hline Wet lime & 15.0 & 36.0 & 1.03 \\
\hline Green manure crops & 11.8 & 20.0 & 0.67 \\
\hline Energy crops & 12.1 & 39.0 & 0.99 \\
\hline \multicolumn{4}{|c|}{ Gray forest soils } \\
\hline Control & 16.4 & 42.0 & 1.00 \\
\hline NPK & 14.2 & 36.0 & 0.86 \\
\hline Wet lime & 18.0 & 30.0 & 0.94 \\
\hline Green manure crops & 16.0 & 38.0 & 0.95 \\
\hline Energy crops & 16.2 & 40.0 & 0.98 \\
\hline \multicolumn{4}{|c|}{ Chernozem soils } \\
\hline Control & 30.2 & 50.0 & 1.00 \\
\hline NPK & 28.2 & 45.0 & 0.92 \\
\hline Wet lime & 29.0 & 39.0 & 0.91 \\
\hline Green manure crops & 30.0 & 58.0 & 1.04 \\
\hline Energy crops & 30.1 & 63.0 & 1.10 \\
\hline \multicolumn{4}{|c|}{ Meadow soils } \\
\hline Control & 38.7 & 63.0 & 1.00 \\
\hline NPK & - & - & - \\
\hline Wet lime & - & - & - \\
\hline Green manure crops & 36.4 & 61.0 & 0.95 \\
\hline Energy crops & 38.0 & 65.0 & 1.01 \\
\hline
\end{tabular}

The proposed operational diagnostics ensures complex demonstration of the efficiency of functioning of the soil, and thus fast elaboration of management events to improve the indices of soil with the purpose of receiving high yields of crops.

Due to the abovementioned method, we calculated the coefficients of functional stability of soils of different genesis. The results obtained confirm high stability of chernozem and meadow soils. The abovementioned $\mathrm{K}$ f.st. for turf-podzolic and other sensitive soils under different loads may serve as an instrument of improving their properties.

\section{Удосконалення методів діагностики зміни екологічного стану грунту під впливом зовнішніх навантажень}
А. С. Холодна, К. О. Десятник
e-mail: lonakalt@gmail.com
Національний науковий центр

Інститут грунтознавства та агрохімії ім. О. Н. Соколовського НААН України Вул. Чайковська, 4, Харків, Україна, 61024

Мета. Оптимізація та спрощення вже існуючих методів екологічної діагностики грунтів різної генези під впливом різноманітних зовнішніх навантажень. Методи. Лабораторно-модельні (фізико-хімічний, біологічний): визначення кислотно-основної буферності грунту (ДСТУ 4456:2005); визначення активності іонів кальцію (ДСТУ 4725:2008); визначення активності протеази за модифікованим методом Мішустіна. Результати. Запропоновані нами методи значно пришвидшують екологічне діагностування грунтів, незважаючи на ї походження та зовнішні чинники. Завдяки цьому спрощується моніторинг грунтових ресурсів та виявляються фактори, що негативно, чи позитивно, впливають на перебіг грунтових процесів. Дані методи покладені в основу «Методології оперативної діагностики впливу природних та антропогенних навантажень на функціональну стійкість кислих грунтів» та можуть бути 


\section{IMPROVEMENT OF METHODS OF ESTIMATING THE CHANGE IN THE ECOLOGICAL STATE OF SOILS}

використані не тільки науковцями в спеціальних наукових установах, але i виробничниками (за умов наявності необхідного мінімуму приладової бази). Висновки. На базі лабораторії родючості гідроморфних та кислих грунтів Національного наукового центру Інститут грунтознавства та агрохімії ім. О.Н. Соколовського НААН України був розроблений модифікований метод фотоавтографії для визначення ферментативної активності за показниками активності протеази. В основу способу покладено метод визначення протеазної активності за Мішустіним. Крім того, завдяки цьому методу можна визначити швидкість дії протеаз в окремих грунтах при різних умовах обробітку та при різних навантаженнях. Діагностика кислотноосновного стану грунтів іон-селективними методами iз визначенням рівнів активності іона кальцію та $\mathrm{pH}$ грунту, моделювання навантажень (природних та антропогенних) на грунти, визначення зміни кислотноосновної буферності грунту під впливом навантажень та визначення біологічної активності через активність протеази за досить короткий термін дає змогу точно визначити функціональну стійкість того чи іншого грунту з метою ii подальшого підвищення/підтримання. В якості фінального етапу проведення діагностування нами запропоновано формулу виведення коефіцієнту функціональної стійкості грунтів (К ф.ст.), виходячи 3 їх генетичних особливостей. Дуже важливим $\epsilon$ й той факт, що дана розробка не потребує високих фінансових затрат, проте дає максимально повну картину стану грунту в поточний період.

Ключові слова: функціональна стійкість, буферна здатність, активність протеази, коефіцієнт функціональної стійкості.

\section{Усовершенствование методов диагностики изменения экологического состояния почв под влиянием внешних нагрузок}

А. С. Холодная, К. А. Десятник

e-mail: lonakalt@gmail.com

Национальный научный центр Институт почвоведения и агрохимии

им. А.Н. Соколовского НААН Украины

Ул. Чайковская, 4, Харьков, Украина, 61024

Цель. Оптимизация и упрощение существующих методов экологической диагностики почв различного генезиса под влиянием разнообразных внешних нагрузок. Методы. Лабораторно-модельные (физикохимические, биологический): определение кислотноосновной буферности почвы (ДСТУ 4456:2005); определение активности ионов кальция (ДСТУ 4725:2008); определение активности протеазы по модифицированному методу Мишустина. Результаты. Предложенные нами методы значительно ускоряют экологическую диагностику почв, не беря во внимание их происхож- дение и внешние факторы. Благодаря этому упрощается мониторинг почвенных ресурсов и выявляются факторы, которые негативно или положительно влияют на ход почвенных процессов. Данные методы положены в основу «Методологии оперативной диагностики влияния природных и антропогенных нагрузок на функциональную устойчивость кислых почв» и могут быть использованы не только учеными в специальных научных учреждениях, но и производственниками (при наличии необходимого минимума приборной базы). Выводы. На базе лаборатории плодородия гидроморфных и кислых почв ННЦ «ИГА имени А.Н. Соколовского» был разработан модифицированный метод фотоавтографии для определения ферментативной активности по показателям активности протеазы. В основу способа положен метод определения протеазной активности по Мишустину. Кроме того, благодаря этому методу можно определить скорость действия протеаз в отдельных почвах при различных условиях обработки и при различных нагрузках. Диагностика кислотно-основного состояния почв ион-селективными методами с определением уровней активности ионов кальция и $\mathrm{pH}$ почвы, моделирование нагрузок (природных и антропогенных) на почвы, определение изменения кислотно-основной буферности почвы под воздействием нагрузок и определение биологической активности по активности протеазы в достаточно короткие сроки, позволяет точно определить функциональную устойчивость той или иной почвы с целью ее дальнейшего повышения/поддержания. В качестве финального этапа проведения диагностики нами предложено формулу вывода коэффициента функциональной устойчивости почв (К ф.уст.), исходя из их генетических особенностей. Важен факт, что данная разработка не требует высоких финансовых затрат, однако дает максимально полную картину состояния почвы в текущий период.

Ключевые слова: функциональная устойчивость, буферность, активность протеазы, коэффициент функциональной устойчивости.

\section{REFERENCES}

1. Methodological guidelines for operational diagnostics of natural and anthropogenic loads influence on the functional stability of acid soils. Ed Yu. L. Tsapko. Kharkiv, Stylna typographia. 2017; 17 p.

2. Truskavetskiy RS. Buffer ability of soils and their main functions. Kharkiv, Nove Slovo, 2003:225 p.

3. Gamkalo MZ, Gamkalo ZG. pH-buffer of soil of Chornohora body of the Carpathian biosphere reserve. Agrohimiya ta gruntoznavstvo. 1998;3:142-3.

4. Zharikova EA. Potential buffer capacity of soils with respect to potassium (by the example of the Amur River region). Eur. Soil Sci., 2004; 37(7):710-7.

5. Zayceva TF. Buffer capacity of soils and the issues of di- 


\section{KHOLODNA et al.}

agnostics. So AN SSSR. Ser. Byoloh., 1987;14(2):64-80.

6. Kanivec VI, Berguleva LYa. Comparative potassium activity and potassium buffer capacity of soils. Agrohimiya. 1975;4:50-56.

7. Kudeyarova AYu. Use of the phosphate buffering capacity index of soils for study of their phosphate regime and substantiation of the effective use of phosphorus fertilizers. Agrohimiya. 1971;11:15-21.

8. Huang C, Zeng G, Huang D, Lai C, Xu P, Zhang C, Cheng $M$, Wan J, Hu L, Zhang Y. Effect of Phanerochaete chrysosporium inoculation on bacterial community and metal stabilization in lead-contaminated agricultural waste composting. Bioresource Technology. 2017;243:294 303. doi: 10.1016/j.biortech.2017.06.124.

9. Xu Q, Li X, Ding R, Wang D, Liu Y, Wang $Q$, Zhao J, Chen $F$, Zeng $G$, Yang $Q, L i H$. Understanding and mitigating the toxicity of cadmium to the anaerobic fermentation of waste activated sludge. Water Res.. 2017;1(124):269-79. doi: 10.1016/j.watres.2017.07.067.

10. Bowles TM, Acosta-Martínez V, Calderón F, Jackson LE. Soil enzyme activities, microbial communities, and carbon and nitrogen availability in organic agroecosystems across an intensively-managed agricultural landscape. Soil Biology and Biochemistry. 2014;68:252-62.

11. Panettieri M, Knicker H, Murillo JM, Madejón E, Hatcher PG.Soil organic matter degradation in an agricultural chronosequence under different tillage regimes evaluated by organic matter pools, enzymatic activities and CPMAS ${ }^{13} \mathrm{C}$ NMR. Soil Biol. Biochem. 2014;78:170-81.

12. Li J, Huang B, Wang $Q$, Li Y, Fang $W$, Han D, Yan D, Guo $M$, Cao A. Effects of fumigation with metamsodium on soil microbial biomass, respiration, nitrogen transformation, bacterial community diversity and genes encoding key enzymes involved in nitrogen cycling. Sci. Total Environ. 2017;15(598):1027-36. doi: 10.1016/j. scitotenv.2017.02.058.

13. Adamczyk B, Karonen M, Adamczyk S, Engström MT, Laakso T, Saranpää P, Kitunen V, Smolander A, Simon J. Tannins can slow-down but also speed-up soil enzymatic activity in boreal forest. Soil Biol. Biochem.2017;107:60-67.

14. Adamczyk S, Adamczyk B, Kitunen V, Smolander A. Monoterpenes and higher terpenes may inhibit enzyme activities in boreal forest soil. Soil Biol. Biochem. 2015;87:59-66.

15. Cao $Q$, Steinman AD, Su X, Xie L. Effects of microcystins contamination on soil enzyme activities and microbial community in two typical lakeside soils. Environ. Pollut. 2017;231(1):134-42. doi: 10.1016/j.envpol.2017.08.013.
16. Li B, Chen Y, Liang $W$, Mu L, Bridges WC, Jacobson AR, Darnault CJG. Influence of cerium oxide nanoparticles on the soil enzyme activities in a soil-grass microcosm system. Geoderma.2017;299(1):54-62.

17. Geisseler D, Scow KM. Long-term effects of mineral fertilizers on soil microorganisms. Soil Biol. Biochem. 2014;75:54-63.

18. Demisie W, Liu Z, Zhang M. Effect of biochar on carbon fractions and enzyme activity of red soil. Catena. 2014;121:214-21. doi.org/10.1016/j.catena.2014.05.020.

19. Yang X, Liu J, McGrouther K, Huang H, Lu K, Guo X, He L, Lin X, Che L, Ye Z, Wang H. Effect of biochar on the extractability of heavy metals $(\mathrm{Cd}, \mathrm{Cu}, \mathrm{Pb}$, and $\mathrm{Zn})$ and enzyme activity in soil. Environ. Sci. Pollut. Res. 2016;23(2):974-84. doi: 10.1007/s11356-015-4233-0.

20. Tyhonenko DG, Gorin MO. Problems of mapping of urban soils. Bulletin of KhNAU.2013;2:5-11.

21. Tyhonenko DG, Gorin MO. Modern state and perspectives of using landscape specifics and soil cover of the territory of the research farm of KhNAU named after V. V. Dokuchaev. Bulletin of KhNAU. 2006;7:3-19.

22. Tsapko YuL, Kholodnaya AS. Changes of biological activity of degraded chernozems in Kharkiv region due to giant miscanthus cultivation. Colloquium-journal. 2017;(10):9-11.

23. Tsapko YuL, Kholodna AS. Protease activity of urban soils of Kharkiv region under the influence of giant miscanthus cultivation. Gruntoznavstvo. 2017;18(1-2):6671.

24. Tepper YeZ, Shylnikova VK, Pereverzeva GI. Practical work in microbiology. Moscow, Kolos. 1993;175 p.

25. Medvedev VV, Plisko IV. Criteria and standards of physical degradation of arable soils (offers on perfecting normative basis). Bull. Agrarian Sci. 2017; 3:11-7.

26. Vranova $V$, Rejsek $K$, Formanek $P$. Proteolytic activity in soil. Appl. Soil Ecol. 2013;70:23-32. doi.org/10.1016/j. apsoil.2013.04.003.

27. Unger $H$. Über den Ausangewert mit dem Gazebeuteltert erzielten Zelluloseabbau Ergebnisse. Tagungsberichte DAL Berlin. 1968;98:16.

28. Mishustin EN, Nikitin DI, Vostrov IS. A direct method for determining the total protease activity of soils. Collection of reports of the soil enzymes symposium. Minsk. 1968;144-50.

29. Vostrov IS, Petrova AN. Definition of microbiological activity of soils by various methods. Microbiologia. 1961;39:66572.

30. Truskavetskiy RS, Tsapko YuL. Estimated indicators of acid-base buffer ability of soils. Agrohimia $i$ hruntoznavstvo. 2003;64:12-16. 